\title{
Development of experimental methodology of investigating the relative and interactive effects of physicochemical properties of permeating fluids on incipient motion of granular particles
}

\author{
Ming Xiao \& Benjamin T. Adams \\ Department of Civil and Environmental Engineering, The Pennsylvania State University, University Park, PA \\ 16802, USA.
}

\begin{abstract}
Particle mobilization is a fundamental aspect in the process of soil erosion and has been known to affect the stability of critical infrastructures such as levees and dams. In the field, fluids permeating through earthen dams or levees may exhibit a range of physicochemical characteristics that may affect the incipient motion of soils. This paper presents an experimental methodology that can be used to evaluate the relative and interactive effects of a fluid's physicochemical properties on the incipient motion of a granular particle under laminar flow condition. The results obtained from the present research demonstrated the ability of the experimental setup and methodology in studying the effect physicochemical properties (such as viscosity, $\mathrm{pH}$ and ionic strength) of fluids on incipient motion of granular particles under laminar flow condition.
\end{abstract}

\section{INTRODUCTION}

Particle mobilization (erosion), transport, and immobilization (clogging) have been studied, in the realm of geotechnical engineering, for the understanding of internal erosion of earthen embankments, such as levees and earthen dams, and the associated filter design. Internal erosion manifests in two major forms: piping and suffusion, such as shown in Figure 1. Internal erosion was blamed for many catastrophic and high-profile failures in the United States, such as the 1972 failure of the Buffalo Creak Dam in West Virginia (Wahler 1973), the 1976 Teton Dam failure in Idaho (Sherard 1987), the 1990 Cyanide Dam failure in North Carolina (Leonards \& Deschamps 1998), the 2004 Upper Jones Tract levee failure in northern California (California DWR 2004), and three levee breaches during the Hurricane Katrina in 2005 (Seed et al. 2008a, 2008b; Sills et al. 2008). A survey conducted on 124 levees and earthen dams that failed or experienced significant damage showed that $46 \%$ of them were due to internal erosion (Foster et al. 2000).

Particle mobilization is a fundamental aspect in the process of soil erosion and involves the balance of forces acting on individual grains within a soil matrix. Some of the potential forces involved in the mobilization process include self-weight (gravity), buoyancy, hydrostatic fluid pressure, inter-particle contact and electrical forces, rotational resistance, and shear forces (Briaud et al. 2008; Fournier et al. 2005; Santamarina 2001). For a sediment particle resting on the surface of a cohesionless sediment bed at the bottom of a flowing fluid, Southard (2006) categorized three kinds of forces acting on the particle: particle weight, particle-to-particle contact forces, and fluid forces that lead to viscous shear stresses and pressure acting at every point on the surface of the particle. A simplified example illustrating some of these forces is shown in Figure 2, where those forces tending to induce particle mobilization include lift, $F_{\mathrm{L}}$, and drag, $F_{\mathrm{d}}$, forces, and the force tending to resist mobilization is frictional in nature, $F_{\mathrm{f}}$. Bedrikovetsky et al. (2011) demonstrated that if the rotational moments caused by the mobilizing forces, $M_{\mathrm{m}}$, exceed the rotational moments caused by the retention forces, $M_{\mathrm{R}}$, a soil particle will become detached and erode. Note that Figure 2 presents a generalized interpretation of the orientation and magnitude of these forces and moments. Many researchers (Gessler 1971; Kramer 1935; Shields 1936; Simons \& Richardson 1966; Tison 1953; Vanoni 1977; White 1940) have studied the initiation of particle motion in sediment beds. The semnal work by Shields (1936) presented the empirical relationship between the dimensionless hydraulic shear stress required for the initiation of particle mobilization (named the Shields parameter, $\theta$ ) and the boundary (or particle, or shear) Reynolds number, $R e_{*}$. Hydraulic shear stress is the tangential stress that a flowing fluid exerts on soil particles. It is caused by the drag force of the fluid and has been shown to directly affect the erosion process (Gilley et al. 1994; Julian \& Torres 2006; Kakuturu \& Reddi 2006a; b). 


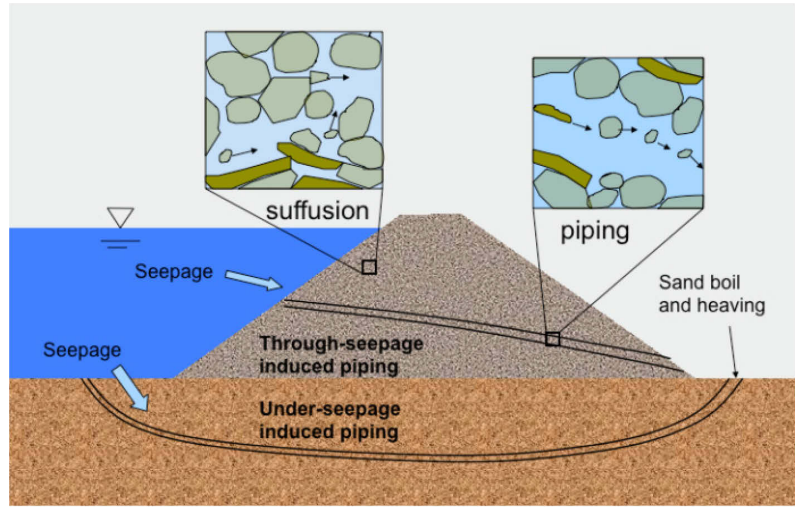

Figure 1. Internal erosion in earthen embankment (Xiao and Shwiyhat 2012).

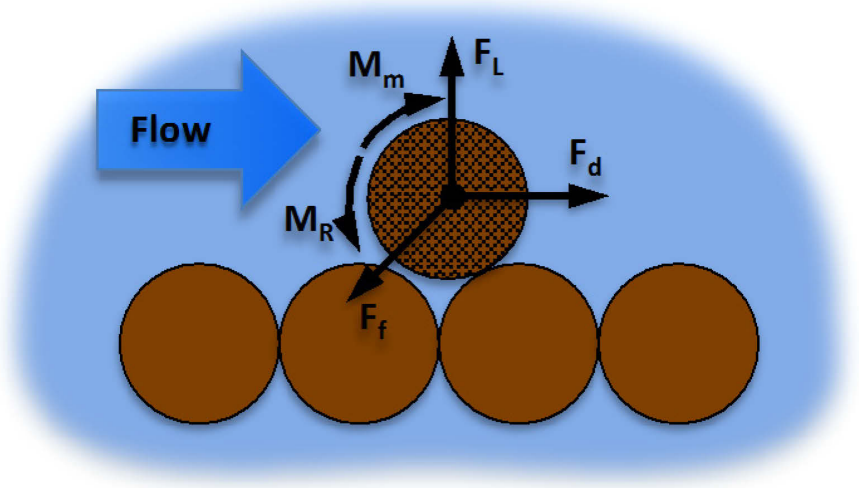

Figure 2. Simplified schematic diagram outlining the interaction of forces during particle mobilization.

In previous experimental studies on soil erosion, including flume tests, the pinhole erosion test, the hole erosion test (HET), and the slot erosion test, tap water or de-ionized water have often been used as the permeating fluid. However, when a fluid permeates through soil and interacts with the environment, its properties are altered from those of pure water (Hillel 1998). In the field, fluids permeating through earthen dams or levees may exhibit a range of chemical compositions and may also contain suspended particles of various sizes and concentrations. For example, during slurry cut-off wall installations in levees, the walls of the excavation are often stabilized by filling the open trench with bentonite slurry. This slurry could seep through the embankment itself or through an existing piping channel. Also, natural seepage in levees and earthen dams may contain dissolved solutes or fine particles that are entrained in the pore fluid during upstream interactions with the environment. Clearly, permeating fluids have the potential to exhibit varying physicochemical properties that differ from those of pure water. Some experiments have demonstrated that permeating fluids consisting of de-ionized water and various concentrations of sodium chloride can induce different erosion behaviors (Arulanandan et al. 1975; Reddi et al. 2000; Yong et al. 1979) and that clogging of soil pores (due to particle deposition) may depend on physicochemical properties of the pearmeating fluids
(Sherard et al. 1984). In the studies on clayey sand specimens, Kakuturu and Reddi (2006a; b) found that permeating fluids with higher viscosity tend to exert higher hydraulic shear stress and cause more erosion. Studies conducted by Hubbe $(1985,1987)$, Sharma et al. (1992), and McDowell-Boyer (1992) attempted to understand the hydrodynamic forces that are required to dislodge particles from flat surfaces. These studies pointed out that the hydrodynamic forces vary with flow rate, particle size, particle elasticity, ionic strength, $\mathrm{pH}$, and the Londonvan der Waal forces and electrical double layer forces between colloidal particles and the surface of the solid matrix. For example, it was demonstrated that erosion potential increases with increasing fluid $\mathrm{pH}$ (Hubbe 1985; Sharma et al. 1992), and decreasing fluid ionic strength (McDowell-Boyer 1992) and particle size (Hubbe 1985) for colloidal particles. A preliminary study by Sinco (2011) suggested that erosion behavior of a clayey sand might be affected by interactions between the permeating fluids' $\mathrm{pH}$, ionic strength, viscosity, and suspended solids composition (plastic and non-plastic) and concentration and that further research is needed to develop an improved understanding of the topic.

The physicochemical characteristics of a permeating fluid that may influence the incipient motion of a particle include viscosity, density, ionic strength, and $\mathrm{pH}$ of the fluids and the suspensions in the fluid. These factors may be interactive, e.g., a change in ionic strength could alter the effect of $\mathrm{pH}$. This paper presents an experimental methodology of investigating the relative and interactive effects of physicochemical properties of permeating fluids on incipient motion of granular particles under laminar flow condition.

\section{METHODOLOGY}

The minimum flow velocity required to mobilize a particle (i.e. the critical velocity) is a function of forces related to certain particle characteristics (density, size, shape, and surface potential), interactions with other particles in the particle matrix (relative locations and interacting forces (Kirchner et al. 1990)), flow conditions, and as hypothesized in this research, certain physicochemical properties of the fluid. To study how a specific factor of interest affects the erosion process requires a representative and robust test setup in which the influence of the other factors is well controlled. Some of these controlled factors depend on the nature of the test particle and its arrangement within the flow field and several design considerations were made with this in mind. For example, a highly spherical ( $>99 \%$ ) sodalime glass bead $\left(\rho=2.5 \mathrm{~g} / \mathrm{cm}^{3}\right)$ measuring $0.69 \pm 0.020 \mathrm{~mm}$ in diameter was used as the test particle. This test particle rested atop a specially de- 
signed "pocket" contained within a customfabricated acrylic flow cell. This particle-supporting pocket comprised three domes protruding from the surface of a flat, smooth, horizontal flow plane (Fig. $3 a)$. The size, protrusion, and orientation of the domes provided three consistent points of support for the test particle by elevating it just above the surface of the underlying plane (Fig 3(b)). Attachment of the flow cell's transparent lid created an enclosed flow area surrounding the test particle and measured $76 \mathrm{~mm}$ in width by $2.6 \mathrm{~mm}$ in height; the support domes and the test particle resided at the centerline of the flow direction. Figure 3(c) shows an overview of the entire flow cell.

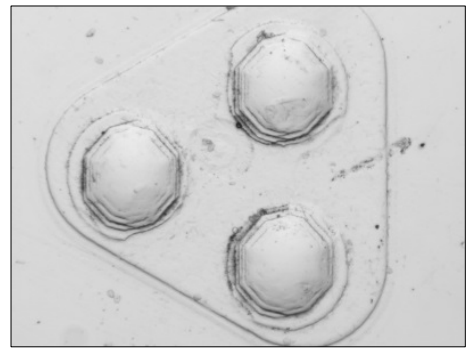

(a)

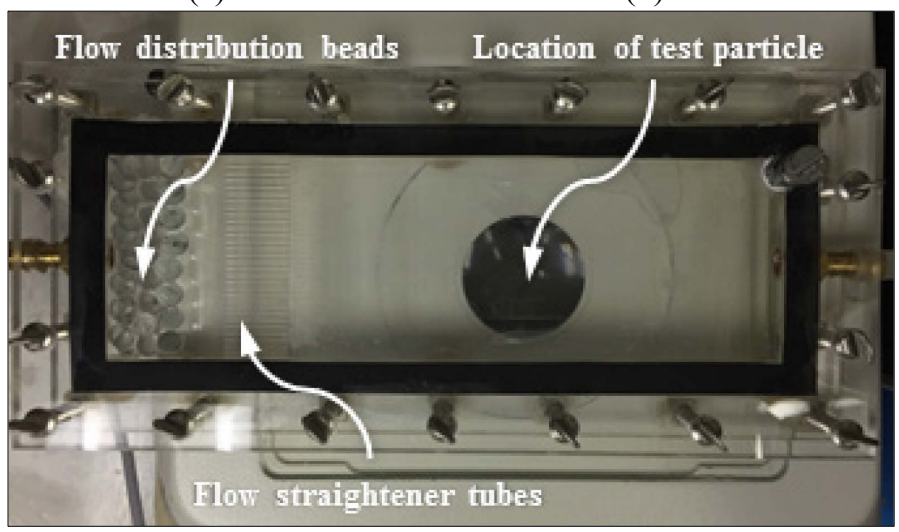

(c)

Figure 3. Close-up plan views of (a) the support domes without a test particle; (b) the test particle resting atop the support domes; and (c) the entire flow cell.

Flow was introduced upon the test particle through flow-straightening tubes machined into the flow cell upstream of the flow area. Before reaching the straightener tubes, the jet of fluid coming through the flow cell inlet was distributed by an assembly of glass beads measuring between 8 and 10 $\mathrm{mm}$ in diameter. The fluid was provided to the flow cell by an upstream constant head reservoir and a controlled hydraulic head difference was achieved by implementing an additional constant-head reservoir downstream of the flow cell. Fluid was recirculated from the downstream reservoir back to the upstream reservoir with a pump. The flow rate between the upstream and downstream reservoir, and thus the flow velocity acting on the test particle, was adjusted as needed with a flow control valve. The combination of these design factors resulted in an experimental setup in which particle mobilization could consistently and repeatedly be achieved within the laminar flow regime that is characteristically devoid of the velocity spikes known to interfere with similar studies made within the turbulent flow regime. The test particle was observed in real-time using a highspeed microscopic video camera outfitted with a zoom lens and mounted above the flow cell. The critical flow velocity was achieved by slowly opening the flow control valve until particle mobilization was observed. Flow velocity around the test particle was calculated based on the flow rate measured with the in-line flow meter upstream of the flow cell. Figure 4 shows an overview of the experimental setup.

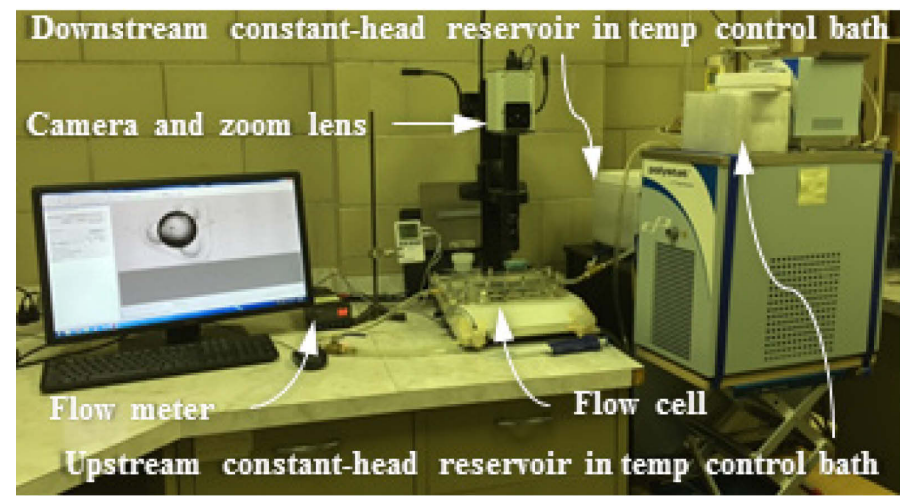

Figure 4. Experimental setup for studying how physicochemical fluid properties affect erosion behavior.

This research focused specifically on verifying the ability of the experimental setup and methodology to produce results on incipient motions of particles that match well with the results of previous researchers. This was accomplished by testing distilled water at a range of temperatures (and thus viscosities) and comparing the results to the well-known Shields diagram. The upstream and downstream constant-head reservoirs were placed within temperature control baths to regulate the temperature. Table 1 summarizes the temperature and viscosity of the eight test fluids. For each fluid, several repeat measurements were made by positioning the test particle to its initial position atop the support domes and reintroducing the flow until the critical velocity was reached.

Table 1. Test fluid temperatures and viscosities

\begin{tabular}{ll}
\hline $\begin{array}{l}\text { Temperature (and fluid ID*) } \\
{ }^{\circ} \mathrm{C}\end{array}$ & $\begin{array}{l}\text { Dynamic viscosity, } \mu \\
\mathrm{kg} / \mathrm{m} \cdot \mathrm{s}\end{array}$ \\
\hline 11.3 & 1.26 \\
11.6 & 1.25 \\
13.3 & 1.19 \\
28.0 & 0.83 \\
28.3 & 0.83 \\
33.3 & 0.75 \\
46.0 & 0.59 \\
46.5 & 0.58 \\
\hline
\end{tabular}

* Numeric value of each fluid's temperature also used as its ID 
For comparison with the Shields diagram, the Shields parameter was calculated as:

$\theta=-\frac{12 \cdot u_{\text {ave }} \cdot y \cdot \mu}{\left(\rho_{s}-\rho_{f}\right) \cdot g \cdot d \cdot h^{2}}$

where $u_{\text {ave }}$ is the average fluid velocity as determined by the measured flow rate and the known cross-sectional area around the particle, $y$ is the vertical distance from the center of the test particle to the center of the flow area, $\mu$ is the fluid's dynamic viscosity as determined from the measured temperature, $\rho_{s}$ is the density of the test particle, $\rho_{f}$ is the density of the fluid as determined by the measured temperature, $g$ is the gravitational acceleration, $d$ is the diameter of the test particle, and $h$ is the height of the flow area around the test particle. The particle Reynolds number was calculated as:

$R e_{*}=\frac{d \cdot \rho_{f} \cdot \sqrt{\frac{12 \cdot u_{a v e} \cdot y \cdot \mu}{\rho_{f} \cdot h^{2}}}}{\mu}$

In order to demonstrate the ability of the experimental methodology to study the effects of physicochemical properties of permeating fluids on incipient motion of granular particles, the viscosity, $\mathrm{pH}$ and ionic strength of the fluids are adjusted to create two test fluids. The upstream and downstream constanthead reservoirs were placed within temperature control baths to regulate the temperature, and thus viscosity, of the test fluid. The $\mathrm{pH}$ of the fluid was adjusted by adding hydrochloric acid $(\mathrm{HCl})$. The ionic strength of the fluid was adjusted by adding sodium chloride $(\mathrm{NaCl})$ and its magnitude was estimated based on measurements of ionic strength. Table 2 summarizes the factor levels of two test fluids used in the present study. For each fluid, ten repeat tests were conducted to obtain the critical velocity at particle incipient motion. The average and standard deviation for each fluid are obtained.

Table 2. Characteristics of two test fluids

\begin{tabular}{c|l|l|c|c}
\hline Test Fluid & $\begin{array}{l}\text { Actual } \\
\text { fluid tem- } \\
\text { perature } \\
\left({ }^{\circ} \mathrm{C}\right)\end{array}$ & $\begin{array}{l}\text { Dynamic } \\
\text { viscosity, } \mu \\
(\mathrm{mPa} \cdot \mathrm{s})\end{array}$ & $\mathrm{pH}$ & $\begin{array}{c}\text { Ionic } \\
\text { strength, } I \\
(\mathrm{~mol} / \mathrm{L})\end{array}$ \\
\hline 1 & 49.7 & 0.55 & 3.5 & 0.3 \\
\hline 2 & 11.4 & 1.30 & 3.4 & 0.3 \\
\hline
\end{tabular}

\section{RESULTS AND ANALYSIS}

The actual critical flow rate at particle incipient motion recorded for the repeated experimental runs at each test temperature were used to compute the average values and standard deviations summarized in
Table 3. These results were plotted on the Shields diagram (with particle Reynolds number from 1.0 to 10.0 as determined in the experiments). Figure 5 shows the experimental data points compare well with the Shields diagram, validating the ability of the experimental setup and methodology to study particle incipient motions of granular particles at laminar flow regime.

Table 3. Summary of test results for distilled water at various temperatures (viscosities)

\begin{tabular}{llllll}
\hline $\begin{array}{l}\text { Fluid } \\
\text { ID } \\
\text { (tem- } \\
\text { pera- } \\
\text { ture, }\end{array}$ & $\begin{array}{l}\text { Number } \\
\text { of } \\
\text { Repeat } \\
{ }^{\circ} \text { C) }\end{array}$ & $\begin{array}{l}\text { Shields } \\
\text { Parame- } \\
\text { ter, } \theta\end{array}$ & $\begin{array}{l}\text { Standard } \\
\text { devia- } \\
\text { tion of } \theta\end{array}$ & $\begin{array}{l}\text { Particle } \\
\text { Reyn- } \\
\text { olds } \\
\text { Number, } \\
R e_{*}\end{array}$ & $\begin{array}{l}\text { Standard } \\
\text { devia- } \\
\text { tion of } \\
R e_{*}\end{array}$ \\
\hline 11.3 & 10 & 0.106 & 0.003 & 1.8 & 0.03 \\
11.6 & 6 & 0.113 & 0.003 & 1.9 & 0.02 \\
13.3 & 4 & 0.126 & 0.007 & 2.1 & 0.04 \\
27.8 & 6 & 0.093 & 0.007 & 2.6 & 0.10 \\
28.3 & 6 & 0.084 & 0.004 & 2.4 & 0.08 \\
33.3 & 10 & 0.084 & 0.007 & 2.7 & 0.12 \\
46.0 & 8 & 0.068 & 0.010 & 3.1 & 0.22 \\
46.5 & 10 & 0.069 & 0.002 & 3.2 & 0.07 \\
\hline
\end{tabular}

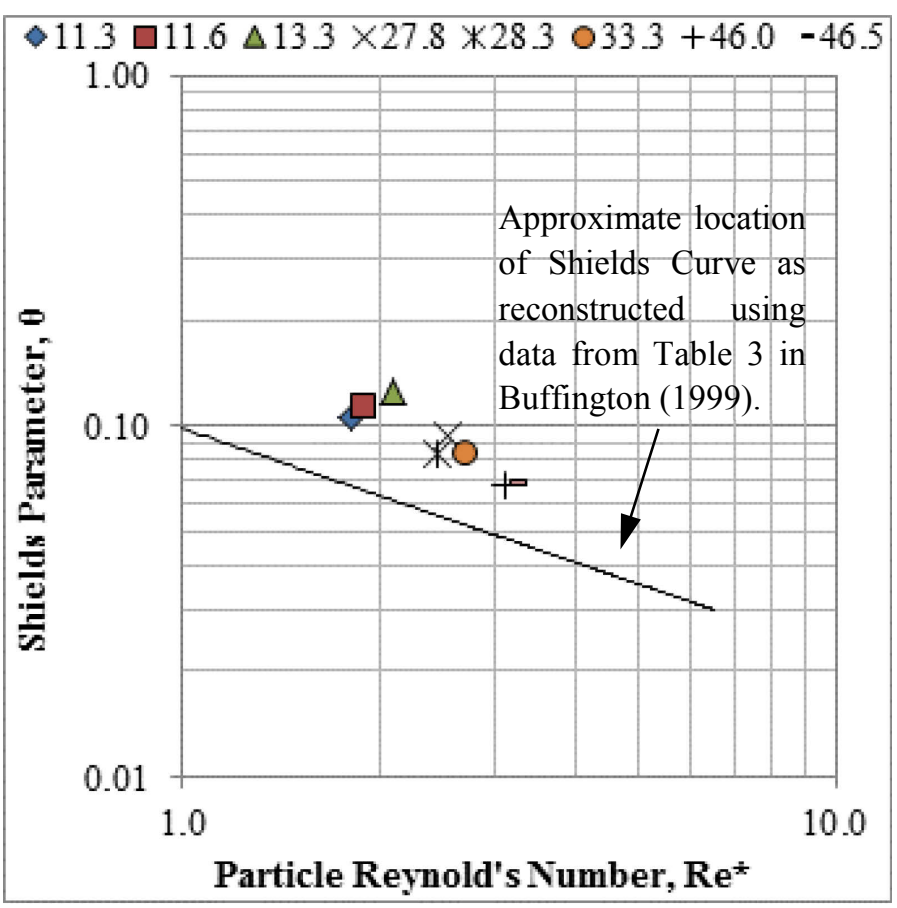

Figure 5. Test results plotted with the traditional Shields Curve.

Table 4 lists the measured critical velocities and calculated average critical Shields parameter, $\theta$, the average flow Reynolds numbers, $R$ e, and the average particle Reynolds number, $R \mathrm{e}_{\mathrm{p}}$. Both Reynolds numbers indicate the flow condition is laminar. Comparisons between test fluids 1 and 2 showed the effect of viscosity on the critical velocity at particle incipient motion - higher dynamic viscosity results in lower critical velocity under laminar flow, when the $\mathrm{pH}$ and ionic strength remained constant. This observation agrees with the current understanding that 
both dynamic viscosity and flow velocity contribute to the hydraulic shear stress (Kakuturu and Reddi (2006a, 2006b), as shown in Equation (3).

$\tau=\frac{4 \mathrm{Q} \mu}{\pi r_{c c}^{3}}$

where $\tau=$ hydraulic shear stress along a cylindrical soil piping channel, $Q=$ flow rate, $\mu=$ dynamic viscosity of the permeating fluid, $r_{\mathrm{cc}}=$ radius of the idealized cylindrical piping channel.

Table 4. Test results for particle incipient motion under the two test fluids

\begin{tabular}{c|c|c|c|c|c}
\hline $\begin{array}{c}\text { Test } \\
\text { Flu- } \\
\text { id }\end{array}$ & $\begin{array}{c}\text { Average } \\
\text { critical ve- } \\
\text { locity, } v_{\text {cr }} \\
(\mathrm{cm} / \mathrm{sec})\end{array}$ & $\begin{array}{c}\text { Standard } \\
\text { deviation of } \\
\text { measured } v_{\text {cr }}\end{array}$ & $\theta$ & $R \mathrm{e}$ & $R \mathrm{e}_{\mathrm{p}}$ \\
\hline 1 & 5.9 & 0.31 & 0.053 & 55.2 & 3.0 \\
\hline 2 & 4.3 & 0.14 & 0.089 & 17.9 & 1.7 \\
\hline
\end{tabular}

\section{SUMMARY AND CONCLUSIONS}

This paper presents an experimental approach that can be used to evaluate the relative and interactive effects of a fluid's physicochemical properties on the incipient motion of a granular particle under laminar flow conditions. The preliminary results obtained from the present research demonstrated the ability of the experimental methodology in studying the effect physicochemical properties (such as viscosity, $\mathrm{pH}$ and ionic strength) of fluids on incipient motion of granular particles under laminar flow condition. Further study to reveal the relative and interactive effects of these fluid properties on particle incipient motions is ongoing.

\section{ACKNOWLEDGEMENTS}

This research is funded by the National Science Foundation CMMI Geomechanics and Geomaterials Program (CMMI 1200081) and The Pennsylvania State University.

\section{REFERENCES}

Arulanandan, K., Krone, R. B., and Longanathan, P. 1975. Pore and eroding fluid influences on surface erosion on soil. Journal of the Geotechnical Engineering Division 101(1): 51-66.

Bedrikovetsky, P., Siqueira, F. D., Furtado, C. A., and Souza, A. L. S. 2011. Modified particle detachment model for colloidal transport in porous media. Transport in Porous $\mathrm{Me}$ dia 353-383.

Briaud, J.-L., Chen, H.-C., Govindasamy, A.V., Storesund, R. 2008. Levee erosion by overtopping in New Orleans during the Katrina Hurricane. ASCE J. of Geotechnical and Geoenvironmental Engineering 134(5): 618-632.

Buffington, J. M. 1999. The legend of A. F. Shields. Journal of Hydraulic Engineering 125(4): 376-387.

California Department of Water Resources (DWR) 2004, June. Photographs of the Upper Jones Tract Levee Break in the Sacramento-

San Joaquin Delta. Retrieved March 12, 2016, from www.water.ca.gov/news/newsreleases/2004/061604floodpi c.pdf

Foster, M., Fell, R., and Spannagle, M. 2000. The statistics of embankment dam failures and accidents. Canadian $\mathrm{Ge}$ otechnical Journal 37(5): 1000-1024.

Fournier, Z., Geromichalos, D., Herminghaus, S., Kohonen, M. M., Mugele, F., Scheel, M., Gessler, J. 1971. Beginning and ceasing of sediment motion. Chap. 7 River Mechanics, H. W. Shen (ed), Water Resources Publication, Littleton, CO.

Gilley, J. E., Kottwitz, E. R., and Wieman, G. A. 1994. Hydraulic conditions required to move unanchored residue materials. Journal of Irrigation and Drainage Engineering 120(3): 591-606.

Hillel, D. 1998. Environmental Soil Physics. Academic Press, San Diego, CA, USA.

Hubbe. M. A. 1985. Detachment of colloidal hydrous oxide spheres from flat solids exposed to flow. 2: mechanism of release. Colloids and Surfaces (16): 249-270.

Hubbe, M. A. 1987. Detachment of colloidal hydrous oxide spheres from flat solids exposed to flow. 3: forces of adhesion. Colloids and Surfaces (25): 311-324.

Julian, J. P., and Torres, R. 2006. Hydraulic erosion of cohesive riverbanks. Geomorphology 76: 193-206.

Kakuturu, S., and Reddi, L. N. 2006a. Mechanistic model for self-healing of core cracks in earth dams. Journal of $\mathrm{Ge}$ otechnical and Geoenvironmental Engineering 132(7): 890-901.

Kakuturu, S., and Reddi, L. N. 2006b. Evaluation of the parameters influencing self-healing in earth dams. Journal of Geotechnical and Geoenvironmental Engineering 132(7): 879-889.

Kirchner, J. W., Dietrich, W. E., Iseya, F., and Ikeda, H. 1990. The variability of critical shear stress, friction angle, and grain protrusion in water-worked sediments. Sedimentology 37(4): 647-672.

Kramer, H. 1935. Sand Mixtures and Sand Movement in Fluvial Models. ASCE Trans. 100: 798-878.

Leonards, G.A., Huang, A.B., and Ramos, J. 1991. Piping and erosion tests at Conner Run Dam. J. of Geotechnical Engineering 117(1): 108-117.

McDowell-Boyer, L.M. 1992. Chemical mobilization of micron-sized particles in saturated porous media under steady flow conditions. Environmental Science Technology 26(3): 586-593.

Reddi, L.N., Xiao, M., Hajra, M. G., and Lee, I.M. 2000. Permeability reduction of soil filters due to physical clogging. ASCE J. of Geotechnical and Geoenvironmental Engineering 126 (3): 236-246.

Santamarina, J. C. 2001. Soil behavior at the microscale: particle forces. Geotechnical Special Publication 119, ASCE, Cambridge, Massachusetts, 25-56.

Seed, R. B., Bea, R.G., Abdelmalak, R. I., Athanasopoulos-Zekkos, A., Boutwell, G.P., Bray, J.D., Cheung, C., Cobos-Roa D., Ehrensing, L., Harder Jr., L.F., Pestana, J.M., Riemer, M.F., Rogers, J.D., Storesund, R., Vera-Grunauer, X., and Wartman, J. 2008a. New Orleans and Hurricane Katrina. II: the central region and the lower Ninth Ward. ASCE J. of Geotechnical and Geoenvironmental Engineering 134(5): 718-739.

Seed, R. B., Bea, R.G., Abdelmalak, R. I., Athanasopoulos-Zekkos, A., Boutwell, G.P., Bray, J.D., Cheung, C., Cobos-Roa D., Cohen-Waeber, J., Collins, B.D., 
Harder Jr., L.F, Kayen, R.E., Pestana, J.M., Riemer, M.F., Rogers, J.D., Storesund, R., Vera-Grunauer, X., and Wartman, J. 2008b. New Orleans and Hurricane Katrina. IV: Orleans East Bank (Metro) Protected Basin. ASCE J. of Geotechnical and Geoenvironmental Engineering 134(5): 762-779.

Sharma, M.M., Chamoun, H., Sita Rama Sarma, D.S.H., and Scgechter, R.S. 1992. Factors controlling the hydrodynamic detachment of particles from surfaces. Journal of Colloidal and Interfacial Science 149(1): 121-134.

Sherard, J.L. 1987 Lessons from the Teton Dam Failure. Engineering Geology 24: 239-256.

Sherard, J. L., Dunnigan, L. P., and Talbot, J. R. 1984. Filters for silts and clays. Journal of Geotechnical Engineering 110(6): 701-718.

Shields, A. 1936. Application of similarity principles and turbulence research to bed-load movement. California Institute of Technology, Pasadena, CA (translated from German).

Simons, D.B. and Richardson, E.V. 1966. Resistance to Flow in Alluvial Channels. USGS Prof. Paper 422-J, Reston, VA, 61p.

Sills, G.L., Vroman, N.D., Wahl, R.E., Schwanz, N.T. 2008. Overview of New Orleans levee failures: lessons learned and their impact on national levee design and assessment. ASCE Journal of Geotechnical and Geoenvironmental Engineering 134(5): 556-565.

Southard, J. 2006. Special Topics: An Introduction to Fluid Motions, Sediment Transport, and Currentgenerated Sedimentary Structures. MIT online course lecture notes, MIT Course Number 12.090, taught in Fall 2006.

Tison, L.J. 1953. Studies of the critical tractive force for the entrainment of bed materials. Proc. Minnesota Inter. Hydraulics Conf., Minneapolis, MN.

Vanoni, V. A. 1977. Sedimentation engineering. ASCE Manual and Reports on Engineering Practice - No. 54, Reston, VA.

Wahler, W.A. 1973. Analysis of coal refuse dam failure, Middle Fork Buffalo Creek, Saunders West Virginia. National Technical Service Rep. PB-215, Washington, D.C.: 142-143.

White, C.M. 1940. The Equilibrium of Grains on the Bed of a Stream. Proc. Royal Society of London, Series A, No. 958, Vol. 174, pp. 322-338.

Xiao, M. and Shwiyhat, N. 2012. Experimental investigation of the effects of suffusion on physical and geomechanical characteristics of sandy soils. ASTM Geotechnical Testing Journal, 35(6): 890-900.

Yong, R. N. Y., Jorgensen, M. A., Ludwig, H. P., and Sethi, A. J. 1979. Interparticle action and rheology of dispersive clays. Journal of the Geotechnical Engineering Division 105(10): 1193-1209. 